\title{
13
}

\section{Insurance and Price Regulation in the Digital Era}

\author{
JAMES DAVEY*
}

\section{Contract, Statute and the 'Price Optimisation' Conundrum}

Price is where contract law places the greatest value on party autonomy, with a corresponding paucity of statutory control. Determining the point at which exchange occurs is routinely treated as an issue for contracting parties and markets to settle, with the role of the state limited in most cases to ensuring competitive markets. ${ }^{1}$ But new forms of technology have reopened the relationship between pricing and regulation. Moreover, there is time lag between the application of these new technologies and the development of regulatory norms. This means that rules not designed for price regulation will need to be adapted or repurposed if regulators are to act. This chapter considers an issue under investigation by the Financial Conduct Authority (FCA) as an archetype: the regulation of pricing of consumer insurance products. At the heart of this is a question about the normative limits of contract: when should regulators step in when consumers overpay for goods or services?

First, some context. Insurance has historically operated on an 'expected loss' model. Insurers paid claims out of the invested premiums of insureds. Premiums were set by estimating (as closely as was economically rational) the level of risk that each insured represented, and adding a figure to cover administrative costs and to provide a profit. This we call the 'risk plus' model.

The application of Big Data ${ }^{2}$ to core insurance activities generates an alternative strategy commonly known as 'price optimisation' or 'price discrimination'. This form

\footnotetext{
* Thanks to the editors, Dr Katie Richards and Professor Christian Twigg-Flesner, for insightful comments during the process.

${ }^{1}$ The proper role of competition law to control any anti-competitive effects of 'price optimisation' is outside the scope of this chapter. See UEA Centre for Competition Policy, 'Financial Conduct Authority: Fair Pricing in Financial Services', (25/01/19) at http://competitionpolicy.ac.uk/publications/responses-to-consultations and more generally R Woodcock, 'Big Data, Price Discrimination, and Antitrust' (2017) 68 Hastings Law Journal 1371.

${ }^{2}$ For the purposes of this chapter, I adopt Rieder's description of Big Data: B Rieder, 'Big Data and the Paradox of Diversity' (2016) 2 Digital Culture \& Society 39.
} 
of market conduct sees contracting parties use sophisticated analytical tools to maximise profitable exchanges, ${ }^{3}$ by predicting the marginal price point at which any given consumer would enter into the contract. ${ }^{4}$ The model was well summarised in a piece in The Actuary, the trade paper of Institute and Faculty of Actuaries:

Why optimise?

Optimisation offers the possibility of achieving higher profitability compared to a straightforward cost-plus approach. The method allows potentially profitable segments of the market to be identified and targeted with attractive premium rates, for example, by accepting low profitability on a policy because of its future cross-selling potential. In particular, these methods enable a company to adjust premiums to allow for differing price sensitivities in different segments of the market. The more information you hold on an individual, the more accurately you can predict their behaviour. ${ }^{5}$

The use of experiential data to price goods and services is not new. ${ }^{6}$ The change is not so much in the nature of the process itself but in the source of the data and the intensity of the calculation. The concept certainly dates back as far as Adam Smith and possibly further. ${ }^{7}$ It is the fundamental basis for much of modern market theory. ${ }^{8}$ Our economic exchanges reveal our preferences. Traders have long used market information to predict future preferences. But the transactions costs associated with the collection and processing of market information necessarily made this insight bounded. Big Data has the potential to dramatically increase the accuracy and reduce the cost of personalising these predictions. If information on preferences is made available more quickly and cheaply, this sounds like perfecting a market. But here's the rub: insurance has long claimed to be priced scientifically by the use of actuarial data. This is the 'risk plus' model that The Actuary proposes abandoning. The quasi-scientific nature of the actuarial process was said to justify the use of information otherwise considered to be socially inappropriate on equality grounds (such as gender, (dis)ability status or sexuality). If the process by which Big Data is operating is no longer actuarial but determining price sensitivity, then many of the justifications that insurers have used to avoid more extensive regulation disappear. There is a 'cake and eat it' feel to this emerging use of technology: insurers demand unfettered access to normally protected characteristics to identify 'accurate' minimum prices, but then want to use Big Data outputs to set prices at an optimal profit level. This gives fresh impetus to a long-standing issue: insurance, price regulation and the role of financial services governance in protecting vulnerable groups. ${ }^{9}$

\footnotetext{
${ }^{3}$ For an example of this approach, see https://cloud.google.com/blog/products/gcp/using-machinelearning-for-insurance-pricing-optimization.

${ }^{4}$ Referred to in micro-economics as the 'reservation point', the points at which a purchaser would not contract above, or a seller below.

${ }^{5}$ J Tanser, 'Insurance: Striking the perfect balance', available at www.theactuary.com/archive/old-articles/ part-2/insurance-3A-striking-the-perfect-balance/?vAction=fntUp.

${ }^{6}$ A Miller, 'What Do We Worry about When We Worry about Price Discrimination - The Law and Ethics of Using Personal Information for Pricing' (2014) 19 Journal of Technology Law \& Policy 41.

${ }^{7}$ D Campbell, 'Good Faith, Adam Smith and the Social Foundation of Agreement: Walford v Miles as a Relational Contract' (2017) 21 Edinburgh Law Review 376.

${ }^{8} \mathrm{~A}$ useful introduction to this theory and scepticism as to its limits is found in C Jolls, C Sunstein and R Thaler, 'A Behavioral Approach to Law and Economics', (1998) 50 Stanford Law Review 1471, 1476.

${ }^{9}$ The literature on economically efficient and/or socially just (insurance) risk classification is extensive. A critical introduction can be found in K Abraham, 'Efficiency and Fairness in Insurance Risk Classification' (1985)
} 
To this, we add a second group: those who are not granted special protection because of some protected characteristic, but who are simply ineffective as consumers. This group is constituted by those who do not choose wisely, and simply buy the same product year-on-year despite rising prices. This is the second major issue that the paper addresses: the shape of modern digital capitalism when seeking to extract maximum value from loyal customers. ${ }^{10}$

These issues are moving with considerable speed from areas of potential concern ${ }^{11}$ to market intervention. Regulators across UK markets are involved, as the practice of charging existing customers above market rates to subsidise new business offers has been the subject of a 'super complaint' to the Competition and Markets Authority by the consumer group, Citizen's Advice. ${ }^{12}$ In response to this, the FCA developed a framework for 'fair pricing' in financial services markets. ${ }^{13}$ The first application of this framework will be in general insurance markets, with final recommendations due in the first quarter of $2020 .{ }^{14}$

The issues sketched out above are evident at this level of abstraction. But they represent the intersection of several branches of complex legal content. Sections II and III of this chapter share a scoping function, identifying the regulatory ecosystem in which price optimisation occurs. This divides into a review of the broader socio-economic goals of statutory regulation of price in part II and analysis of the specific statutory controls in section III.

In section IV, I develop a plan of action for regulators. This is three-fold:

(1) enhanced use of the Equality Act controls on direct and indirect discrimination for those with protected characteristics;

(2) recognition that the existing regulatory framework is ill-suited to deal with consumers who fail to actively choose on the basis of price; and

(3) identifying the research agenda to fill this lacuna.

71 Virginia Law Review 403. Consideration of these issues in the UK / EU context is found in J Davey, 'Future imperfect: human genetics and insurance' [2000] Journal of Business Law 587 and 'Genetic discrimination in insurance: lessons from Test Achats' in G Quinn, A De Paor and P Blanck (eds), Genetic Discrimination Transatlantic Perspectives on the Case for a European Level Legal Response (Abingdon, Routledge, 2014).

${ }^{10}$ An extremely useful review of the economic analysis of the field is found in RG Thomas, 'Non-Risk Price Discrimination in Insurance: Market Outcomes and Public Policy' (2012) 37 Geneva Papers on Risk and Insurance 27.

${ }^{11}$ J Davey and M Bek, 'Insurance and Big Data' (University of Southampton, 2015), available at https:// eprints.soton.ac.uk/381274.

${ }^{12}$ www.citizensadvice.org.uk/about-us/how-citizens-advice-works/media/press-releases/citizens-adviceissues-super-complaint-as-loyal-customers-continue-to-be-penalised-by-over-4-billion-a-year.

${ }^{13}$ FCA, 'Fair Pricing in Financial Services: summary of responses and next steps' (FS19/04, 2019), following on from FCA, 'Pricing Practices in the retail general insurance sector: Household insurance' (TR18/4, 2018). In addition to the papers above, see FCA 'Fair Pricing in Financial Services' (DP18/9; 2018); M Starks, G Reynolds, C Gee, G Burnik and L Vass, 'Price discrimination in financial services: How should we deal with questions of fairness?' (2018); FCA, 'Price discrimination and cross-subsidy in financial services' (September 2016); FCA, 'Increasing transparency and engagement at renewal in general insurance markets- feedback on CP15/41 and final rules and guidance' (PS16/21, 2016).

${ }^{14}$ FCA, 'General Insurance Pricing Practices: Interim Report' (MA18/1.2, 2019). 


\section{Price Optimisation, Adam Smith's Invisible Hand and Freedom of Contract}

\section{A. The Law and Economics of Price: A Brief Introduction}

The legal, economic and social mechanisms that determine the price at which products are offered in markets has been a key focus of micro-economics during the past 250 years. Most accounts of contract law assume that the determination of price is a matter for the parties. This is consistent with the account that the basis for contract is voluntariness (as for many contract scholars) and a routine assumption for those who favour efficiency (much of the remainder). ${ }^{15}$ There are some circumstances in which the courts might be involved in determining the price payable, but these are largely limited to circumstances where the parties appear to agree, but having failed to specify the price, nonetheless act as if bound. ${ }^{16}$ These I treat as conceptually different from regulatory action to overturn an explicitly agreed price. For reasons of space, I do not examine them in this chapter.

By contrast, price controls have been used as part of the process of privatising previously nationalised industries. The macro-economic justification for this is the existence of natural monopolies in the provision of many utilities and analogous structural explanations for the lack of a competitive market in those goods or services. ${ }^{17}$ The most commonly adopted model, attributed to work by Dr Stephen Littlechild in the 1980s, is 'RPI -X', which focused on profitability of regulated industries being made dependent on finding efficiencies above a pre-determined level (the ' $\mathrm{X}$ ' factor). ${ }^{18}$ Space prevents a fuller account of this model, but price controls act as a mechanism to incentivise the reduction of cost of delivery in key services where markets cannot be made competitive. These controls are applied at the macro level to products including transport, power and water utilities. The issues in financial services markets are not directly analogous, and arise not because of a natural monopoly, but because technological change enables the ability of the industry to fragment existing markets to obtain additional value by separating the price sensitive from the insensitive.

Regulation of price within competitive markets is modelled quite differently. I adopt here Avery Katz's useful précis of the dominant model:

$[\mathrm{M}]$ ost positive economic analysis continues to be based on a specific and distinctive account of human behavior: that of constrained optimization. This theory posits that economic actors

\footnotetext{
${ }^{15}$ An excellent introduction is N Oman, The Dignity of Commerce: Markets and the Moral Foundations of Contract Law (Chicago, University of Chicago Press, 2017), chs 2, 4.

${ }^{16}$ The empowerment of judges to determine a reasonable price in certain markets is an underconsidered aspect of the Victorian codification of commercial law. See eg Marine Insurance Act 1906, s 31(1) and Sale of Goods Act 1979, s 8(2). See further J Gilman, C Blanchard and M Templeman, Arnould: Law of Marine Insurance and Average, 19th edn (London, Sweet \& Maxwell, 2018) [6-01] and M Bridge, Benjamin's Sale of Goods, 10th edn and 1st Supp (London, Sweet \& Maxwell, 2018) [2-046]-[2.047].

${ }^{17}$ See also here the regulation of 'roaming' costs for the use of mobile phones and other data services across EU borders: Council Regulation (EU) No 531/2012 of 13 June 2012 on roaming on public mobile communications networks within the Union [2012] OJ L172/10.

${ }^{18}$ A McHarg, 'Evolution and Revolution in British Energy Network Regulation: From RPI-X to RIIO' in M Roggenkamp, L Barrera-Hernández, D Zillman and I del Guayo, Energy Networks and the Law: Innovative Solutions in Changing Markets (Oxford, Oxford University Press, 2012).
} 
are best described as pursuing a consistent set of goals as fully as possible within the constraints of time, money, attention, and other relevant resources ... Elucidation of the theory in this example yields the standard predictions of microeconomics, including the fundamental law of demand, which posits that an increase in an item's price, other things being equal, results in a decline in consumer demand for the item. ${ }^{19}$

For the purposes of this chapter, this concept of consumer preferences, and their effect on pricing, is key. For any given consumer, the optimal price point for a commercial party is where the customer will pay its maximum price for the good or service:

The theory of constrained optimization (sometimes referred to by the ambitious title of 'rational choice theory') does not require that the actor only be interested in material benefit; nor does it require that she have access to all relevant information or calculate without error, or that her goals be determined in isolation from the influence of others. It only presumes that she has a coherent and well-defined set of goals, together with preferences for choosing among goals in the event they come into conflict. What the theory does require, however, is that the actor's preferences remain stable over the period of observation and prediction, and most importantly, that such preferences are determined independently of the constraints that limit them. ${ }^{20}$

The 'boundedly rational consumer' model was used to generate a highly influential price/ quality terms dichotomy. This is derived from the work of the Nobel Prize-winning economist, George Akerlof, and his 'Market for Lemons' paper. ${ }^{21}$ If boundedly rational consumers are not able to (rationally) distinguish between high-quality and low-quality products, then traders will be forced by market pressure to produce low-quality, inexpensive goods. Regulation might then logically step in to require minimum quality standards, and we see this in the quality obligations in the Consumer Rights Acts 2015 and the like. ${ }^{22}$ The reverse point is often overlooked. Akerlof assumes that consumers are readily able to compare products on the basis of price, and so this need not be regulated.

As Hayek argued, what this model loses in its assumption of economic rationality is the concept of radical ignorance. ${ }^{23}$ In a market of rational economic actors, a consumer will choose not to know something when it is boundedly rational to remain ignorant. There are - to reuse Rumsfeld's famous analysis - only 'known unknowns. ${ }^{24}$ But real markets do not operate on this basis. There are things of which consumers are ignorant because they do not know what they could know: the 'unknown unknowns'. Hayek's account of the necessary limits of state action depend on his assertion that the state is no better position than any other actor to know best how to allocate resources. It is submitted that much of the difficulty in designing the response to price optimisation is our

\footnotetext{
${ }^{19}$ A Katz, 'Economic Foundations of Contract Law' in G Klass, G Letsas and P Sarpai, Philosophical Foundations of Contract Law (Oxford, Oxford University Press, 2015) 173.

20 ibid.

${ }^{21}$ G Akerlof, ‘The Market for “Lemons”: Quality Uncertainty and the Market Mechanism' (1970) 84 Quarterly Journal of Economics 488.

${ }^{22}$ Consumer Rights Act 2015, s 9 and Sale of Goods Act 1979, s 14.

${ }^{23}$ F Hayek, 'The Use of Knowledge in Society' (1945) 35 American Economic Review 519, and the analysis of this paper in P Boettke, F.A. Hayek: Economics, Political Economy and Social Philosophy (London, Palgrave, 2018) esp ch 4: 'Hayek on Market Theory and the Price System'.

${ }^{24}$ D Rumsfeld, Department of Defense news briefing (12 February 2002).
} 
inability to distinguish on a case-by-case basis which consumer choices are boundedly rational and which are the product of radical ignorance. I will return to this in part IV.

One final fundamental should be noted. Whilst the object of microeconomics is often the individual consumer decision, commercial counterparties are often only able to observe those preferences as part of mass market behaviour. In most markets, it is the collective effect rather than individual preferences that can be measured. At the heart of this chapter is a change, driven by Big Data analytics, in the 'granularity' of commercial parties' ability to observe preferences, to move from judging pricing effects across markets down to the level of the individual. This brings us much closer to Adam Smith's initial vision of consumer preferences:

[D]irecting that industry in such a manner as its produce may be of the greatest value, [the consumer] intends only his own gain, and he is in this, as in many other cases, led by an invisible hand to promote an end which was no part of his intention. ${ }^{25}$

\section{B. Risk Classification and Pricing Regulation in Modern Insurance Markets}

The ability of state and private entities to allocate individuals to particular groups has long been recognised as a significant element in the operation of society. ${ }^{26}$ Insurance pricing, where based on actuarial risk classification is a fundamental example of this, and has been subject to state control since at least the 1970s. The form that regulation has taken has varied considerably across jurisdictions, and represents a key political choice.

The regulatory state on both sides of the Atlantic imposes substantial restrictions on the negotiation and performance of insurance contracts, but in overtly different ways. Broadly speaking, the US model is concentrated on ex ante approval of policy limits and pricing structures, with ex post regulation handled chiefly by judicial intervention by means of interpretative techniques and a range of substantive duties arising by implied terms in contract and through tort. ${ }^{27}$ By contrast, the UK model assumed a broadly contractarian approach to formation and performance with substantive legal rules generally protecting the insurer from moral hazard concerns that arise from the insured's conduct. ${ }^{28}$ The later addition of a raft of regulatory controls is applied ex post, as part of a licensing regime. British insurers are not required to seek pre-approval of

\footnotetext{
${ }^{25}$ A Smith, Wealth of Nations, Glasgow edn (Oxford, Oxford University Press, 1975) 456.

${ }^{26}$ On the effect on society structures of categorising citizens, see J Simon, 'The Ideological Effects of Actuarial Practices' (1988) 22 Law \& Society Review 771. For insurance specific examples, see R Ericson, A Doyle and D Barry, Insurance as Governance (Toronto, University of Toronto Press, 2003) and D Bouk, How Our Days Became Numbered (Chicago, University of Chicago Press, 2015).

${ }^{27}$ See D Schwarcz, 'Ending Public Utility Style Rate Regulation in Insurance' (2018) 35 Yale Journal on Regulation 941.

${ }^{28} \mathrm{~A}$ useful introduction can be found in R Ford, 'History: a history of insurance regulation in the UK', and a more detailed review in J Smethurst, W Heukamp, J Goodliffe and R Miller, 'Conduct of Business Regulation: a survey of the UK regime and a comparison with the US, German and HK approach', both in J Burling and K Lazarus (eds), Research Handbook on International Insurance Law and Regulation (Cheltenham, Edward Elgar, 2012).
} 
policy terms or premium schemes, even when dealing with consumers. Rather, we see a familiar version of an EU law consumerist model, with regulated information flows and the control of performance on an open-textured 'standards' (rather than rules) basis. So, insurers are required by regulatory code to 'treat customers fairly', to provide information prior to contracting and to not reject claims without good reason. These regulatory standards are reviewed in detail below in part III.

What this means is that US regulators have a pre-existing set of tools which can be readily applied to control price optimisation. Dan Schwarcz noted the rise of the phenomenon, and the existence of regulatory models to combat it within US law:

Price optimization refers to the practice, employed by some insurers, of pricing coverage based in part on inferences about the price sensitivity of individual policyholders. For instance, an insurer might increase rates on renewing policyholders not because of an increase in expected costs, but because it believes renewing customers are unlikely to actively shop for alternative coverage. Such price optimization rather clearly violates the prohibition against 'unfair discrimination' in insurance. Moreover, competition is unlikely to eliminate price optimization, because the practice specifically targets the consumers who are least likely to be responsive to the practice. ${ }^{29}$

As will be shown below, English law has no pre-existing regulatory model which responds directly to price optimisation. Unlike the US, with its extensive system of price regulation in insurance, the UK has adopted an ex post system of regulation of insurance outcomes, rather than an ex ante system of approving rates and coverage models. Pricing decisions are - for the most part - unregulated in English insurance law and so price optimisation is, by default, similarly outside the limits of state intervention. This means that the FCA will need to repurpose existing legislative controls, such as the unfair terms or data protection legislation, the Equality Act 2010, or develop its delegated powers under the Financial Service and Markets Act 2000 (as amended) if it wishes to regulate prices.

\section{The Legislative Basis for Price Regulation}

\section{A. Introduction}

General contract law and insurance contract law are normally satisfied if the parties have concluded a voluntary exchange and are largely indifferent as to whether the exchange is balanced. That is a matter for market forces. As Chitty puts it:

[A]s a general rule the courts do not concern themselves with the question whether 'adequate' value has been given, or whether the agreement is harsh or one-sided. The fact that a person pays 'too much' or 'too little' for a thing may be evidence of fraud or mistake, or it may induce the court to imply a term as to the quality of the subject-matter or be relevant to the question whether a contract has been frustrated. But it does not of itself affect the validity of the contract ... ${ }^{30}$

\footnotetext{
${ }^{29}$ Schwarcz, 'Public Utility Style Rate Regulation' (2018) 984.

${ }^{30} \mathrm{H}$ Beale, Chitty on Contracts, 33rd edn (London, Sweet \& Maxwell, 2018) [4-014].
} 
This general principle has exceptions to it, although they are limited. The rules described have different origins, instrumental purposes, and levels of enforcement. Our immediate goal is to complete the first detailed survey of the ecosystem in which regulators must operate. We take in turn: the unfair terms system; the data protection regulations; equality law; and financial services regulation.

\section{B. Unfair Terms and Price Regulation}

A paradigmatic example of the regulatory and judicial unwillingness to regulate price is the unfair terms legislation 'bank charges' case of OFT $v$ Abbey National. ${ }^{31}$ This provides the closest analogy to the developing situation in the insurance market. The justiciability of unfair prices under the legislation has been largely consistent in its various guises in the Unfair Terms Regulations of 1994 and 1999 and the Consumer Rights Act 2015 (CRA 2015). The general rule is that all terms in consumer contracts are subject to potential review, ${ }^{32}$ unless they fall within certain exceptions. Most pertinently for this chapter, contractual clauses may not be reviewed for fairness insofar as that relates to an assessment 'of the appropriateness of the price payable under the contract by comparison with the goods, digital content or services supplied under it. ${ }^{33}$ This does not exclude price terms from review per se, ${ }^{34}$ but the court is not entitled (without more) to consider 'the quality/price ratio of a supply of goods or services. ${ }^{35}$ This exclusion from review was at the heart of the Abbey National case and it remains an important authority.

The issue before the Supreme Court involved the fees charged on those who used unarranged overdrafts. The comparison with the price optimisation in insurance is a logical one, as it involved a substantial cross-subsidy flowing between groups of customers:

The banks accept that the system of 'free-if-in-credit' banking prevalent in this country involves a significant cross-subsidy (amounting to about 30\% of the banks' total revenue stream from current account customers) provided by those customers who regularly incur charges for unauthorised overdrafts (a cohort, we were told, of the order of 12 million people) to those customers (a cohort of about 42 million people) who are in the fortunate position of never (or very rarely) incurring such charges. ${ }^{36}$

The Supreme Court viewed retail bank accounts as a basket of services - some free; some costly - against which the price was demanded. Lord Walker's view (confirmed by the majority) was that issues related to price were excluded by the 'core issues' exemption of price:

When one turns to the other part of the quid pro quo of a consumer contract, the price or remuneration, the difficulty of deciding which prices are essential is just the same, and regulation 6(2)(b) contains no indication that only an 'essential' price or remuneration is relevant.

\footnotetext{
${ }^{31}$ Office of Fair Trading $v$ Abbey National Plc [2010] 1 AC 696.

${ }^{32}$ CRA 2015, s 62.

${ }^{33}$ CRA 2015, s 65(1)(b).

${ }^{34}$ See Lord Mance JSC in Abbey National (n 31) [101].

${ }^{35}$ Case C-26/13 (ECLI:EU:C:2014:282) Kásler v OTP Jelzálogbank Zrt [2014] Bus LR 664 [55].

${ }^{36}$ Above n 31, per Lord Walker, [1].
} 
Any monetary price or remuneration payable under the contract would naturally fall within the language of paragraph (b). ${ }^{37}$

The court took comfort in its approach by reference to an article by Hugh Collins, which explained the underlying ethos of EU consumer contract as correcting asymmetric information rather than substantive fairness:

The Directive does not require consumer contracts to be substantively fair, but it does require them to be clear. Clarity is essential for effective market competition between terms. What matters primarily for EC contract law is consumer choice, not consumer rights. ${ }^{38}$

This vision of consumer protection as a guarantee of process, rather than outcome, is explicit in Lady Hale's brief assent:

As a very general proposition, consumer law in this country aims to give the consumer an informed choice rather than to protect the consumer form making an unwise choice. We buy all sorts of products which a sensible person might not buy and some of which are not good value for money. We do so with our eyes open because we want the product in question more than we want the money. ${ }^{39}$

As regards price, this refocuses the locus of intervention on ensuring that consumers can understand the price they are to be charged, and away from the regulation of fair pricing. Under the 1999 Regulations being interpreted in the Abbey National case, a price clause would be exempt 'in so far as it is in plain intelligible language. ${ }^{40}$ This is different from a requirement that consumers understand how the price has been calculated, and is a focus on the visibility of the end point. One significant doctrinal change should be noted at this point. In the move to the CRA 2015, clauses must now be both 'transparent' (an extension of the 'plain intelligible language' test) and 'prominent' in order to be exempt from regulation as a pricing issue. ${ }^{41}$ The hypothetical consumer envisaged by the Act in the application of these tests is 'reasonably well-informed, observant and circumspect, ${ }^{42}$ and provides little protection for consumers who fail to reach this standard. This is closer to the 'boundedly rational' market participant of Akerlof than to the empirically derived accounts from behavioural economics. ${ }^{43}$

The CJEU has, in subsequent case law, provided a useful explanation of the purpose of the 'core issues' exclusion insofar as it relates to price. The tensions that exist between the Supreme Court and the European court are evident from this line of case law, and suggest that the CJEU is less committed to the vision of consumer protection as protecting choice. Nonetheless, for the purposes of this chapter I contend these differences are almost certainly not critical: on my reading, neither model would actively intervene where a consumer overpays for financial services, save some failure of transparency. Whilst the declared position of the European Court post-Abbey National looks to be

\footnotetext{
${ }^{37}$ Above n 31, [41].

${ }^{38}$ H Collins, 'Good Faith in European Contract Law' (1994) 14 Oxford Journal of Legal Studies 229, 238.

${ }^{39}$ Above n 31, [93].

${ }^{40}$ Unfair Terms in Consumer Contracts Regulations 1999 (SI 1999/2083), reg 6(2)(b).

${ }^{41}$ CRA 2015, s 64(2)-(4).

${ }^{42}$ CRA 2015, s 64(5).

${ }^{43} \mathrm{~A}$ useful summary of the behavioural science in this field is found in E Zamir and D Teichman, Behavioral Law and Economics (Oxford, Oxford University Press, 2018) 292-304.
} 
somewhat more interventionist than the Supreme Court in the Abbey National case, it still falls some way short of providing a solution to the price optimisation issue. The differences between the UK and CJEU position need to be unpacked.

Matei ${ }^{44}$ building on the decision in Kásler ${ }^{45}$ made clear that it had not been possible to design a regulatory system to establish the proper ratio between price and the quality of service: 'that exclusion being explained by the fact that no legal scale or criterion exists that can provide a framework for, and guide, such a review. ${ }^{46}$ This represents a particular view of the operation of market exchange, and its relationship to law. This does not mean that certain pricing strategies could not be found to be anti-competitive, or unfair commercial practices. Behaviours can be identified as illegitimate. What the CJEU is asserting is that it is not possible for law to determine in any particular situation what the fair price would have been. As above, this is conceived as regulation of the process of exchange, and not as review of the substantive outcome.

The quality:price ratio is then a matter for market pressure brought to bear by the operation of the preferences of individual consumers, operating within a regulated market economy. This presents a fundamental challenge to the use of unfair terms legislation to counter price optimisation. Price regulation would need to develop a vision of consumer harm that can be usefully applied in order to inform the assessment of fairness on a case-by-case basis. The standard measure, with considerations of substantive and procedural fairness, is open textured and might be thought readily applicable to reviewing price. However, this is subject to the objection raised by the CJEU in respect of the reviewability of price terms: 'no legal scale or criterion exists that can provide a framework for, and guide, such a review. ${ }^{37}$ It is the very lack of a model for determining what a fair price would be (by comparison to the goods provided) that determined the non-justiciability of the issue. What matters in this context is transparency of pricing, and the ability of consumers to find a cheaper competitor. ${ }^{48}$ The refusal to regulate the magnitude of the price is not a matter of normal judicial competence (whether Parliament has authorised the regulation of this issue), but of legal capacity: no such guide for review can exist, within the current conception of markets. This matches the position adopted by the (albeit limited) subsequent English case law on the area. ${ }^{49}$ Recall that this exclusion from review is all subject to the requirement that the terms be (in modern parlance) transparent and prominent. This, as was made clear in Kásler, is not simply a formalist requirement that the clause 'should be grammatically intelligible to the consumer', but also required that the hypothetical consumer could understand the function of the clause:

[T] he contract should set out transparently the specific functioning of the mechanism, so that that consumer is in a position to evaluate, on the basis of clear, intelligible criteria, the economic consequences for him which derive from it. ${ }^{50}$

\footnotetext{
${ }^{44}$ Case C-143/13 (ECLI:EU:C:2014:127) Matei v SC Volksbank România SA [2015] 1 WLR 2385.

${ }^{45}$ Kásler (n 35).

${ }^{46}$ Above $n$ 44, [55].

${ }^{47}$ For the origins of this view, see the text to $\mathrm{n} 52$ below.

${ }^{48}$ Case C-92/11 (ECLI:EU:C:2013:180) RWE Vertrieb AG v Verbraucherzentrale Nordrhein-Westfalen eV [2013] 3 CMLR 10.

${ }^{49}$ Casehub Ltd v Wolf Cola Ltd [2017] 5 Costs LR 835 [46], which repeats the approach in Kásler.

${ }^{50}$ Above n 35, [75].
} 
This latter step is beyond what the Supreme Court discussed in Abbey National, and has yet to be developed fully. As considered below, it is unlikely that either court would develop this into a requirement that the consumer be given sufficient information so that it can understand how it has been manipulated, even if such a standard could be designed.

The theoretical basis for the denying capacity to regulate price can be traced through the Matei / Kásler case law, but requires a study of the opinions of the Advocates-General. Unlike in the Supreme Court, the secondary materials were not cited directly. The court in Kásler referenced the opinion of $\mathrm{AG}$ Wahl, ${ }^{51}$ which is a relatively unusual step for the court to make. On closer inspection, his explanation of the unwillingness of EU consumer law to regulate price was derived from an article by Schillig, ${ }^{52}$ which is itself an application of Akerlof's classic 'Market for Lemons' paper. ${ }^{53}$

The underlying assumption behind Akerlof's piece is that many markets are determined by price rather than by a detailed consideration of the terms on which the goods or services are offered, and that this is boundedly rational. To avoid a 'race to the bottom' in the quality of non-price terms, law intervenes to remove the competitive advantage from providers who undercut on price by worsening the position of the consumer in the non-price terms. This can be achieved by imposing minimum quality standards, requiring the timely disclosure of information, consumer education or a myriad of other mechanisms, but the intervention is said to be justified by the (relative) inattention of consumers to non-price issues. Crucially, and this is the central tenet of Schillig's mapping of the EU unfair terms provisions, he contends that the reverse is true. Price ratios need not be regulated because consumers pay attention to price terms and market forces control the value. What is therefore needed is a requirement that the pricing mechanisms not be hidden or opaque, so that consumers can actively choose based on price. This gives us the 'not regulated, if prominent and transparent' model for price issues under unfair terms legislation.

The nature of the unfair terms approach to price is a product of the regulatory concerns at the time of drafting the legislation, ${ }^{54}$ and has been credibly explained by Schillig as based on concerns over 'markets for lemons' type problems. This conception of the market works poorly for aspects of the digital economy, including optimisation, where traders are able to identify consumers that are not price-sensitive, and segregate them from others who would require the trader to price competitively. This destabilises the Schillig model, as he assumes that as long as sufficient ${ }^{55}$ numbers of consumers in

\footnotetext{
${ }^{51}$ Above n 34, Opinion of AG Wahl [23].

${ }^{52}$ M Schillig, 'Directive 93/13 and the "price term exemption": a comparative analysis in the light of the "market for lemons" rationale' (2011) 60 ICLQ 933.

${ }^{53}$ Akerlof, 'The Market for "Lemons"' (1970).

${ }^{54} \mathrm{H}$ Brandner and P Ulmer, 'The Community Directive on Unfair Terms in Consumer Contracts: Some Critical Remarks on the Proposal Submitted by the EC Commission' (1991) 28 Common Market Law Review 647, esp 656.

${ }^{55}$ Schillig, "Directive 93/13 and the "price term exemption"' (2011) 958 references on this point the findings of A Schwartz and L Wilde, 'Intervening in Markets on the Basis of Imperfect Information: A Legal and Economic Analysis' (1979) 127 University of Pennsylvania Law Review 630 that a ratio of around one-third active to two-thirds passive consumers will suffice.
} 
the market are actively selecting between products on the basis of a given criterion, that there will be effective market pressure for traders to offer acceptable terms to all consumers. But a technology that enables traders to segregate active consumers from passive ones means that the market will be largely constituted of consumers who are not price sensitive.

The statutory controls in the unfair terms regime are deliberately founded on the concept of enhancing consumer choice - better information, more readily available and not on the substitution of the state's choices for those of the consumer. Outside of those markets in which natural monopolies exist, in utilities such as water, electricity and transport, price has been determined by markets. Even where statutory intervention on welfarist grounds has been introduced, it has largely restricted itself to the clarity of price to be charged, rather than to any assessment as to the value for money provided by any good or service.

On that basis, we move on to a second area of consumer protection: the restrictions on the use of consumer data contained in the General Data Protection Regulations (GDPR) and associated national legislation.

\section{Data Protection as Price Regulation}

The newly enacted Data Protection Act 2018 provides an enhanced system of checks and balances on the use of consumer data and integrates UK law into the broader GDPR scheme. As a method of price control, it is relatively weak in nature, as it provides (in general) for a system of informed consent, ${ }^{56}$ and this will normally be readily available for insurers seeking to access client data for underwriting purposes. Under the General Data Protection Regulation $2016^{57}$ (which is directly applicable in the UK), ${ }^{58}$ certain types of data are given enhanced protection under art 9 , including personal data related to 'racial or ethnic origin, political opinions, religious or philosophical beliefs, or trade union membership' There are further controls on the processing of 'genetic data, biometric data for the purpose of uniquely identifying a natural person, data concerning health or data concerning a natural person's sex life or sexual orientation. These controls are subject to the granting of explicit consent (art $9(2)(a))$ and other exemptions such as the proportional pursuit of a substantial public interest $(\operatorname{art} 9(2)(\mathrm{g})))$.

Under English law, there is an additional specific 'insurance exemption' in sch 1, para 20(1) for data processing without the consent of the prospective insured. This is

\footnotetext{
${ }^{56}$ L Feiler, N Forgó and M Weigl, The EU General Data Protection Regulation (GDPR): A Commentary (Woking, Globe Law, 2018).

${ }^{57}$ Council Regulation (EU) 2016/679 of 27 April 2016 on the protection of natural persons with regard to the processing of personal data and on the free movement of such data, and repealing Directive 95/46/EC (General Data Protection Regulation) [2016] OJ L119/1.

${ }^{58}$ The future shape of the cross-border controls on data usage is dependent on the precise outcome of the Brexit process, although something similar to the current position appears to be the desired outcome of the UK government. See https://ico.org.uk/about-the-ico/news-and-events/blog-data-protection-andbrexit-ico-advice-for-organisations.
} 
implemented under the 'substantial public interest' principle in art $9(2)(\mathrm{g}){ }^{59}$ There are a series of nested conditions, requiring that the processing:

(a) is necessary for an insurance purpose,

(b) is of personal data revealing racial or ethnic origin, religious or philosophical beliefs or trade union membership, genetic data or data concerning health, and

(c) is necessary for reasons of substantial public interest.

An equivalent provision exists for personal data related to criminal convictions. ${ }^{60}$ The Data Protection Act 2018 imposes further conditions where the data being processed does not relate directly to an insured, ${ }^{61}$ but these are outside the scope of this chapter. What we have for the insured's personal data as used in insurance pricing is a general requirement of specific consent, but with an exception that removes even this requirement for insurance underwriting decisions where the use of the data 'is necessary for reasons of substantial public interest'. On this basis, these 'privacy' rights are assumed not to provide any substantial barrier to the use of price optimisation, at least once legacy systems and data have been made compliant. ${ }^{62}$ We therefore progress to more promising areas of potential control.

\section{The Equality Act 2010 as Price Regulation}

With respect to protected characteristics, ${ }^{63}$ the Equality Act 2010 (and related statutes) substantially limited insurers' general freedom at common law to use personal information in pricing risk. The obvious limit is that it does not apply to factors outside those characteristics, at least not unless there is some form of indirect discrimination on protected groups. To facilitate this discussion, we begin with a summary of the competing normative standards that are used across UK statutes to regulate underwriting practices. The introduction of the 2010 Act was part of the process of extending the range of protected characteristics but saw relatively little change in the formal governance of discriminatory underwriting. The definitions of direct and indirect discrimination (in ss 13(1) and 19 of the Equality Act 2010) apply to insurance and specific attention is given to the discriminatory provision of services in s 29 . The effect of this provision is to constrain the underwriter's ability to refuse to provide insurance, or to provide it on different terms.

This general principle of non-discrimination based on protected characteristics is then amended by detailed bespoke provisions that apply to insurance and related

\footnotetext{
${ }^{59}$ Schedule 1 is given this effect by virtue of DPA 2018, s 10.

${ }^{60}$ Sch 1 , para 37.

${ }^{61}$ Sch 1 , para 20(2),(3),(4).

${ }^{62}$ This is not meant to underestimate the cost of transition nor the sanctions for non-compliance, which I understand to be considerable.

${ }^{63}$ Equality Act 2010, s 4: 'The following characteristics are protected characteristics - age; disability; gender reassignment; marriage and civil partnership; pregnancy and maternity; race; religion or belief; sex; sexual orientation'
} 
products. Whilst further variations have been proposed, ${ }^{64}$ English law largely adopts one of four positions, which are given in increasing level of intervention:

(1) 'Fair discrimination' (non-intervention): The general position is for personal information to be unregulated, as necessary for the accurate assessment of risk, and calculation of price. This concept is a cornerstone of the actuarial and insurance industries case to government for minimal regulation. It assumes that market forces not only permit, but require, insurers to have access to all risk-related information when assessing risk. Otherwise, hidden subsidies will flow from the protected class from all others and distort insurance demand. This is the formal legal position for risk factors outside of the protected characteristics listed in the 2010 Act. ${ }^{65}$ This model is strongly reliant on rational choice theory, a vision of risk underwriting as objective and the consequences of 'adverse risk selection'; 66

(2) 'Reasonable Actuarial Basis': This model is currently used for factors related to age and disability and was previously used in relation to sex discrimination. This could be considered the standard UK intervention (where one is enacted) and treats unequal treatment after risk assessment as discriminatory unless based on actuarial (or similar) evidence. This, it has been said, is treating like cases alike, and disparate cases differently. However, the limits of this provision have been tested infrequently and provide only limited evidence of the extent of the justification.

(3) Privacy: Outside of the Equality Act regime, the law related to the disclosure to insurers of 'spent' criminal convictions provides the prospective insured with a right not to disclose that sensitive information. This privacy right is limited by the lack of any commensurate obligation on the underwriter to not consider such information if it has access to it by other means. This is added to by data protection legislation, but only to the extent to which 'particularly sensitive' data is controlled. ${ }^{67}$ Alongside the formal legal rules, the Association of British Insurers has a 'good practice' guide that goes beyond the minimum statutory protections. ${ }^{68}$

(4) Prohibition: The use of a limited number of characteristics, and this most obviously includes race, can never be justified under English law. Sex discrimination was moved to this category from category 2 following the decision of the European

\footnotetext{
${ }^{64}$ Within US law, for example, there is a range of normative models under consideration. See K Abraham, Distributing Risk: Insurance, Legal Theory and Public Policy (New Haven, Yale University Press, 1986); R Avraham, K Logue and D Scwarcz, 'Understanding Insurance Antidiscrimination Laws' (2014) 87 Southern California Law Review 195 and R Avraham, K Logue and D Schwarcz, 'Towards a Universal Framework for Insurance Anti-Discrimination Laws’ (2015) 21 Connecticut Insurance Law Journal 1.

${ }^{65}$ The Rehabilitation of Offenders Act 1974 adopts a privacy model, rather than controlling the underwriter use of data once revealed.

${ }^{66}$ Adverse risk selection assumes that high-risk insureds will 'over consume' subsidised insurance cover where their high-risk status is excluded from risk assessment. See T Baker 'Containing the Promise of Insurance: Adverse Selection and Risk Classification' (2002-03) 9 Connecticut Insurance Law Journal 371. For an excellent challenge to the 'objective' conception of the underwriting process, see Glenn's discussion of the 'myth of the actuary' in B Glenn, 'The Shifting Rhetoric of Insurance Denial' (2000) 134 Law \& Society Review 779. An excellent contrarian position in actuarial science can be found in $\mathrm{R}$ Thomas, Loss Coverage: Why Insurance Works Better with Some Adverse Selection (Cambridge, 'Cambridge University Press, 2017).

${ }^{67}$ See section C above, 'Data Protection as Price Regulation.'

${ }^{68}$ ABI, 'Insurers' Approach to People with Convictions and Related Offences' (2019).
} 
Court of Justice in Test Achats. ${ }^{69}$ This is not to say that actuarial evidence does not exist to suggest differences in risk, the legal prohibition denies access to these factors even where demonstrably related to risk. For example, there are uncontested differences identifying the distribution of certain medical conditions according to racial factors (eg sickle cell anaemia) but even then such data is prohibited for risk classification.

There have been very few instances of judicial enforcement of these standards and much of the case law predates the legislative consolidation brought about by the Equality Act 2010. The 'level 2' protection requiring evidence to justify differential treatment as found in the Sex Discrimination Act 1975 proved to be limited in effect, because the courts required only a simple actuarial correlation between the increased price and the factors considered. So, in Pinder $v$ Friends Provident,${ }^{70}$ a female dentist charged considerably more for her cover had no grounds for review as her classification as 'female' and therefore higher risk was supported by actuarial evidence, with no need to show that this was a best practice or reasonable risk classification structure. In particular, the insurer was not required to show that female dentists represented a higher risk than male dentists; it was sufficient that females generally were higher risk than males. This interpretation of the insurance exception ${ }^{71}$ placed considerable emphasis on the justificatory limb of the test 'where the [unequal] treatment was affected by reference to actuarial or other data' rather than the caveats that followed 'from a source on which it is reasonable to rely' and where it 'was reasonable to have regard to the data and any other relevant factors'. In this we see the common problem of market practice being considered lawful because it constituted existing market practice (Hume's 'the is becoming the ought') rather than a detailed consideration of the appropriate limits of market conduct.

The choice between the application of levels 1-4 is not (at the time of writing) a matter solely for English law, as the Test Achat decision ${ }^{72}$ confirmed that EU law required that sex discrimination be prohibited in insurance pricing, and that any provision to the contrary was ultra vires. Within the UK, this was achieved by amendment of the Equality Act 2010, so as to delete the permissive rule found in sch 3, para 22 relating to sex discrimination. ${ }^{73}$

The decision in respect of sex discrimination in Test Achats had political and legal ramifications, in respect of existing protected characteristics, and the potential extension of that list. These are most obvious in respect of age and genetic status. Paragraph 20A provides a general presumption that age discrimination cannot arise in the provision of financial services. ${ }^{74}$ However, where the financial service provider carries out a risk assessment, that immunity is only available (under para $20 \mathrm{~A}(2)$ ) if 'carried out by reference to information which is relevant to the assessment of risk and from a source on which it is reasonable to rely'. This clarification of the

\footnotetext{
${ }^{69}$ Case C-236/09 (ECLI:EU:C:2011:100) Association Belge de Consommateurs Test Achats ASBL $v$ Conseil de Ministres [2012] 1 WLR 1933.

${ }^{70}$ (1985) 5 EOR 31. See K Khan 'Sexual discrimination in insurance' (1986) 136 New Law Journal 839.

${ }^{71}$ At that time: Sex Discrimination Act 1975, s 45.

72 Above $n 71$.

${ }^{73}$ Equality Act 2010 (Amendment) Regulations 2012, SI 2012/2992.

${ }^{74}$ As defined in para $20 \mathrm{~A}(3)$.
} 
potential for age discrimination in insurance, annuities and pensions came into force on 1 October 2012, by way of statutory instrument. This clarification of the age discrimination model was no doubt forced by the most significant judicial intervention in this account, the CJEU's decision in Test Achats. By contrast, the disability rules in para 21 do not offer a presumption that discrimination does not arise in financial services but offers an exception to the s 29 requirement of equal treatment in respect of insurance business where the unequal treatment is based upon relevant and reasonable actuarial evidence.

By contrast to the statutory models above, the use by insurers of positive genetic test results in pricing risk was covered by a 'soft law' code of conduct enshrined in a moratorium agreed between industry and government. This prohibited the use of positive genetic test results below certain currency thresholds, and to tests approved as relevant and reliable by quango. ${ }^{75}$

To summarise, the non-discrimination rules provide a useful check on the ability of algorithmically driven pricing structures, and at two distinct levels. First, they control certain forms of data as protected characteristics. However, the enforcement of these controls (at least judicially) has been limited and this is no surprise as the likelihood of individual consumer enforcement of these rights is fanciful. Moreover, there are good reasons to doubt that simple controls on AI pricing will be effective. ${ }^{76}$ Secondly, the prohibition on indirect discrimination provides a means of reviewing outcomes and not merely inputs. The choice of price optimisation as a system is then made subject to review, if it has indirectly discriminatory effects, even if the data used is compliant with the requirements to not directly discriminate in setting prices. This is an important part of the arsenal available to the FCA, and its application is considered in detail in part IV.

\section{E. Regulation by Code: The FCA Regulation of Insurance under Delegated Powers ${ }^{77}$}

The FCA is empowered by the Financial Services and Markets Act 2000 (as amended) to regulate a defined set of markets, which includes the insurance market. Given the nature of this project, it is important to establish the statutory basis for FCA action. It has a series of statutory objectives: a strategic objective under $\mathrm{s} 1 \mathrm{~B}(2)$ : to ensure 'that the relevant markets ... function well' and three operational objectives under s $1 \mathrm{~B}(3)$ of consumer protection, integrity and competition. In these functions it supersedes the Financial Services Authority, which was broken up following the global financial crash of 2008 .

\footnotetext{
${ }^{75}$ See R Stirton, 'Insurance, Genetic Information and the Future of Industry Self-Regulation in the UK' (2012) 4 Law, Innovation and Technology 212. The current code, the Code on Genetic Testing and Insurance (2018) is now open-ended, unlike previous iterations which were time limited. See www.abi.org.uk/globalassets/files/publications/public/genetics/code-on-genetic-testing-and-insurance_embargoed.pdf.

${ }^{76}$ A Prince and D Schwarcz, 'Proxy Discrimination in the Age of Artificial Intelligence and Big Data' (2020) Iowa Law Review (forthcoming).

${ }^{77}$ www.handbook.fca.org.uk/handbook.
} 
The interrelationship of these objectives is obviously key, as they will not all pull in the same direction on some issues. Section 1B(4) seeks an accommodation as follows:

The FCA must, so far as is compatible with acting in a way which advances the consumer protection objective or the integrity objective, discharge its general functions in a way which promotes effective competition in the interests of consumers.

In the legal hierarchy, 'effective competition' is set as the primary public good, with consumer protection given a lesser status.

Consistent with the vision of consumer markets enshrined in the unfair terms legislation, the expectation is of protecting consumers by the mandating of timely and useful information in the expectation that consumers will then make rational welfare-maximising choices. This is not the exclusive vision of the regulatory agenda: the consumer protection objective enshrined in the statute recognises the heterogeneous nature of consumers and their needs. ${ }^{78}$ The assumption is that consumers for the most part lack the information needed for them to gain the full benefits of their role in the market economy as active choosers. Section $1 \mathrm{C}(2)(\mathrm{c})-(\mathrm{d})$ requires the FCA to have regard to 'the needs that consumers may have for the timely provision of information and advice that is accurate and fit for purpose' and 'the general principle that consumers should take responsibility for their decisions'.

There is no direct instruction in the primary legislation to regulate prices. This is distinct from the powers given to the bodies that oversee the former nationalised industries. Moreover, when full consideration is made of the detailed codes that the FCA has generated in its period as regulator, it is apparent that these also do not deal with price directly, and regulatory capacity has to emerge from reliance on extremely broad principles of fair treatment and the like. This is in fairly stark contrast to the detailed provisions that have been promulgated, revised and enforced in respect of both substantive principles of insurance contract law (related to formation and breach) and to the proper use of mandated information as a mechanism for improving market outcomes.

The shape of FCA regulation in can appear arcane to those unfamiliar with the system, but for the purposes of this work we can reduce the system to two distinct levels: high level standards (which apply broadly across all markets as a whole) and specific codes (here, the Insurance Conduct of Business Sourcebook (ICOBS)).

Given the nature of the high level standards, many will apply to the use of price optimisation, but the FCA has relied most heavily on principle 6: 'Customers' interests: A firm must pay due regard to the interests of its customers and treat them fairly'. This has become colloquially known by the acronym TCF: 'treat customers fairly', but must be read in light of principle 5: 'A firm must observe proper standards of market conduct' and 7: 'A firm must pay due regard to the information needs of its clients, and communicate information to them in a way which is clear, fair and not misleading. ${ }^{79}$ The concept of fairness is then embedded in the vision of market intervention that underpins this; it is the avoidance of situations in which active consumers were unable to make effective market choices because of a lack of relevant information rather than the direct revision of inequalities of bargaining power.

\footnotetext{
${ }^{78}$ FMSA 2000, s 1C(b),(f) (as amended).

79 'High level standards - Principles' (Prin 2.1), www.handbook.fca.org.uk/handbook/PRIN/2.
} 
The regulatory image is not too distant from Collins' famous statement on EU consumer law that what mattered in exchange was not fairness but transparency. ${ }^{80}$ Consumers need, under this view, enough information to make 'good' choices, and not further paternalistic intervention in the bargain agreed. This does not mean that the FCA is limited to these kinds of interventions - it has wide ranging powers - but it does shape the nature of its agenda.

We move now from the high-level principles of behaviour expected of licensed market participants to the specific rules set out in ICOBS. A full review of the entire code is well beyond the scope of this paper, but there is a now familiar mixture of rules which require firms to follow best practice, to act in the best interests of customers and to provide information at key points. As with common law rules, there is a risk that this enshrines majoritarian market positions with the assumption that if everyone does it, it must be right. ${ }^{81}$ It should be noted that many of these rules are judicially enforceable for breach of statutory duty but only by private persons. ${ }^{82}$

ICOBS 2.5 therefore states: 'A firm must act honestly, fairly and professionally in accordance with the best interests of its customer'. In respect of price (and remuneration), the regulatory focus is on making transparent the payments to insurers and intermediaries. ICOBS 4.3 makes this mandated disclosure a key element of precontractual conduct: 'In good time before the conclusion of a contract of insurance, an insurance undertaking must provide its customer with information on the nature of the remuneration received by its employees in relation to the contract of insurance.'

But there are no rules which deal explicitly with the 'value for money' question. As with the unfair terms legislation, the focus lies on competition and information as the key drivers of ensuring that markets operate effectively. In light of this, the FCA's sudden enthusiasm for price regulation in the face of technology is a departure from its normal arena. In the final section below, I explore the evolution of this regulatory vision, the legal impediments to its implementation, and some ways around those obstacles.

\section{Price Optimisation and Regulation}

\section{A. Introduction}

The FCA announced in July 2019 its intention to regulate to ensure 'fair pricing. ${ }^{83}$ The particular focus of this is the issue of 'legacy pricing' whereby rates for new customers are subsidised by loading prices of existing customers. The report seeks to explain the model for intervention, but does not explain in any detail the legal basis under which it will act. Broadly speaking, it reflects the approach in this chapter, that certain groups of consumers require particular protection, and that a further model must be developed for consumers in general.

\footnotetext{
${ }^{80}$ A Georgosouli, 'Payment Protection Insurance (PPI) Misselling: Some Lessons from the UK' (2014) 21 Connecticut Insurance Law Journal 261.

${ }^{81}$ D Howarth, 'Negligence after Murphy: Time to Re-think' (1991) 50 CLJ 58, 68-69.

${ }^{82}$ Financial Services and Markets Act 2000, s 138D (as amended).

${ }^{83}$ FCA, 'Fair Pricing in Financial Services: summary of responses and next steps' (FS19/04, 2019).
} 
The FCA model is only a sketch of an approach, and undeveloped in terms of detail. In essence, it will measure the need to intervene by consideration of six factors (in the table below) ${ }^{84}$ and will select the method of intervention on a sliding scale. The first test of this, with the application of these standards to the review of pricing in the general insurance market. ${ }^{85}$

\section{i. Identifying Harm}

Table 13.1 Six evidential questions on distributive fairness

\begin{tabular}{|l|l|l|}
\hline Question & \multicolumn{1}{|c|}{ Mitigating factor } & \multicolumn{1}{c|}{ Aggravating factor } \\
\hline $\begin{array}{l}\text { Who is harmed by price } \\
\text { discrimination? }\end{array}$ & $\begin{array}{l}\text { Wealthier consumers, eg } \\
\text { time-poor, cash-rich }\end{array}$ & $\begin{array}{l}\text { Consumers with } \\
\text { characteristics which might } \\
\text { be deemed vulnerable (eg low } \\
\text { income, old age, etc) }\end{array}$ \\
\hline $\begin{array}{l}\text { How significant is the pool of } \\
\text { people harmed? }\end{array}$ & Very small minority & $\begin{array}{l}\text { Significant group of } \\
\text { consumers }\end{array}$ \\
\hline $\begin{array}{l}\text { How are firms price } \\
\text { discriminating? }\end{array}$ & $\begin{array}{l}\text { Transparent and based on } \\
\text { behaviour which consumers } \\
\text { can easily change (eg } \\
\text { switching) }\end{array}$ & $\begin{array}{l}\text { Hidden and based on } \\
\text { intrinsic characteristics } \\
\text { which consumers cannot } \\
\text { easily change (eg personal } \\
\text { characteristics) }\end{array}$ \\
\hline $\begin{array}{l}\text { Is the product / service } \\
\text { essential? }\end{array}$ & $\begin{array}{l}\text { Product / service is } \\
\text { considered non-essential but } \\
\text { desired by some consumers }\end{array}$ & $\begin{array}{l}\text { Essential product/service (eg } \\
\text { current account or motor } \\
\text { insurance) }\end{array}$ \\
\hline $\begin{array}{l}\text { Would society view the price } \\
\text { discrimination as egregious/ } \\
\text { socially unfair? }\end{array}$ & $\begin{array}{l}\text { Little concern expressed } \\
\text { about practices and firm } \\
\text { behaviour widely accepted }\end{array}$ & $\begin{array}{l}\text { Persistent and broad-based } \\
\text { concern expressed and firm } \\
\text { behaviour seen as poor } \\
\text { conduct }\end{array}$ \\
\hline
\end{tabular}

To the lawyer's eye these look much more like the kind of assessments of fairness under unfair terms legislation, with its blend of procedural and substantive unfairness than the Learned Hand approach. In interpreting the limits of fairness in the previous generation of unfair terms legislation, Lord Bingham in DG of FT $v$ FNCB described the test as one 'of fair and open dealing. Openness, he said, 'requires that the terms should be expressed fully, clearly and legibly, containing no concealed pitfalls or traps. Appropriate prominence should be given to terms which might operate disadvantageously to the customer. ${ }^{86}$ This would apply mutatis mutandis to pricing factors. Fair dealing is

\footnotetext{
${ }^{84}$ See Figure 3'Six evidential questions on distributive fairness' in M Starks, G Reynolds, C Gee, G Burnik and L Vass, 'Price discrimination in financial services: How should we deal with questions of fairness?' (FCA, July 2018) 5 .

${ }^{85}$ Above $n 13$.

86 [2002] 1 AC 481 [17].
} 
concerned less with process than with effect and requires that a supplier should not, whether deliberately or unconsciously, take advantage of the consumer's necessity, indigence, lack of experience, unfamiliarity with the subject matter of the contract, weak bargaining position ....87

There is a difficulty here which the FCA must face down. The unfair terms legislation was described as incapable of applying to pricing decisions precisely because 'that exclusion being explained by the fact that no legal scale or criterion exists that can provide a framework for, and guide, such a review. 88 If the FCA is capable of producing a test for identifying overpricing on a case-by-case basis for any given consumer for price optimisation, then it is confounding accepted wisdom in the unfair terms sphere. If such a legal scale can exist, and can be defined by the FCA, then why can it not be applied across all markets? Why should it be restricted in its ambit to the regulation of price optimisation? Recall that the European Court of Justice did not say that EU consumer law had chosen not to regulate price, but that it lacked the legal technique to do so. The challenge for the FCA is not just the technical challenge of identifying consumer harm caused by pricing, but of keeping that regulatory tool within check, and of not permitting its proliferation across consumer law.

\section{ii. Identifying the Correct Method of Intervention}

The scale of 'harm' identified above is likely to be replicated in a corresponding scale of interventions. Given the absence of specific controls on price optimisation, the likely response is an extension of existing practice. The previous work carried out by the FCA on pricing at renewal was both information-based and behaviourally informed. ${ }^{89}$ It consisted of mandatory information at renewal, providing price comparability information, such as the level of premium for the previous year. Alongside this, firms had to provide a prompt to encourage active choosing by consumers, along the lines of: 'Have you checked that your insurance cover still meets your needs? Have you considered shopping round to find the best deal for the cover you want?' At the fourth renewal, the reminder became more overtly 'libertarian paternalistic' in nature, with a mandatory statement included: 'You have been with us a number of years. You may be able to get the insurance cover you want at a better price if you shop around. ${ }^{90}$

What follows are proposals to extend the method of intervention beyond this vision as information as market corrective. In doing so, I explore underused existing regulatory tools in this area (the Equality Act 2010) and the next steps for building a coherent regime in insurance pricing.

\footnotetext{
${ }^{87} \mathrm{ibid}$.

${ }^{88}$ Above n 44, [55].

${ }^{89} \mathrm{FCA}$, 'Increasing transparency and engagement at renewal in general insurance markets - feedback on CP15/41 and final rules and guidance' (PS16/21, 2016), reflecting research published as FCA, 'Occasional Paper 12 - Encouraging consumers to act at renewal: Evidence from field trials in the home and motor insurance markets' (2015).

${ }^{90}$ In PS16/21 (ibid) [2.21].
} 


\section{B. The FCA Vision of Price Regulation in Insurance: The Regulatory Basis}

The survey of the regulatory eco-system in part III identified two likely sources of FCA control (equality law and FCA codes), and two areas where action would appear to be less credible (unfair terms and GDPR). We can separate out these two areas of action into the general and the specific. The FCA codes apply across all regulated entities, and this includes insurers, and to interactions with all customers. It is, in this sense, general. It is also general in that it protects a range of interests, including a competitive market and consumer protection. By contrast, the Equality Act rules are specific in that they control the relationship with discrete subsets of consumers, and only protect a narrow range of interests, chiefly equal (or equivalent) treatment. This section proceeds by considering the case for intervention on the basis of the specific Equality Act rules before progressing to the general case.

\section{i. Markets, Protected Characteristics and 'Risk Based Pricing'}

Insurers have long argued that risk information is vital to accurate pricing in order to ensure that lines remain profitable. This would suggest that private law rules ought to generate (or at least facilitate the generation of) risk data at placing, with minimal state interference in the use of the data in pricing. ${ }^{91}$ This is the 'fair discrimination' model used routinely in the twentieth century. ${ }^{92}$ This is a coherent argument if pricing was set on a 'risk plus' basis, and there was no case for redistribution. It is broadly consistent with a prudential model of insurance pricing by which the financial stability of insurers is driven by (on average) successful underwriting of each individual risk. But the model discussed in The Actuary is based on a differential approach, that similar risks are not priced on the same basis. The approach of underwriters is more akin to supermarket pricing, with special offers on some goods used to attract customers for more profitable lines. The subsidies run from existing customers to new ones and from less price sensitive groups to more. This is, and this is ironic to say the least, contrary to the detailed arguments deployed to support 'fair discrimination' and for the insurance industry to be made exempt from many Equality Act 2010 controls. ${ }^{93}$ Those arguments focused on the unfairness of hidden subsidies: from men to women (or vice versa). This, it was said, was a matter for the state to operate by way of taxation and benefits, and an ill-deserved distortion of the insurance market and pricing process.

There is a need to bring the private and public law vision of insurance pricing into the twenty-first century and to provide a principled basis for so doing. A core element of this will need to be differentiating between protecting the financial stability of insurers and fair pricing. At present, these issues have not been sufficiently clearly differentiated in the 'fair discrimination' debate.

\footnotetext{
${ }^{91}$ This is often traced to the statements of Lord Mansfield in Carter $v$ Boehm (1766) 3 Burr 1906, 1909.

${ }^{92}$ J Gaulding, 'Race Sex and Genetic Discrimination in Insurance: What's Fair' (1994-95) 80 Cornell Law Review 1646.

${ }^{93} \mathrm{~N}$ Cameron and F Hawke, 'Vive La Difference? Non! ECJ decides Mean and Women are Equal Before the Law and Before the Underwriter' (2011) 22 Insurance Law Journal 118.
} 
Let us define two processes. For now, as a thought experiment, we will treat them as distinct, even though there may be real-world costs in running them separately. First, insurers need to set a price for each customer. We will call this the 'underwriting' moment. Second, insurers need to generate sufficient income to cover costs and claims. In a capitalist economy, we could assume that an insurer will also wish to make a profit on top of this figure, but this could be additional footfall for related businesses, or personal data, and not simply an immediate financial return. This we can call the 'audit' moment.

The existence of the second element, which does not attract significant regulatory attention in most commercial relationships, has been used to justify a differential outcome in the first. This is it is assumed to be a social good that insurance companies do not become insolvent. We are less concerned if a supermarket underprices goods to the extent that its business model is unsustainable. But insurance is a 'pay first, receive performance later' model, and so fiscal stability is much more highly valued. ${ }^{94}$

Historically, private law rules in insurance assume that information must either be disclosed, or can otherwise be required, and equality rules have specific exceptions that permit insurers use of this data (sometime within further conditions of use). But these exceptions could be restricted to the second process: the 'audit' point. In any mass market product with a sufficiently high-volume book, it would be possible to separate the price decision from the audit decision. There would need to be a feedback loop 'is the audit position looking healthy or concerning?' - but this need not change the contracting process for individual customers other than on a standard supply/demand basis.

If this change in pricing model occurs, then the underwriter does not have any special claim to privileged information, it can rely on the macro estimate made by the audit team. The shift from 'risk plus' as the baseline for insurance pricing means that those markets fall outside the justification given under 'fair discrimination' models for access to sensitive risk data. This is now just a regulated capitalist exchange. This is the end of insurance exceptionalism in risk data, at least for those markets.

This can be realised without changes to primary legislation. The provisions of the Equality Act 2010 that relate to insurance have not always been given the close scrutiny that they deserve. What follows is a more critical, and purposive, analysis of the effect of equality legislation on insurance. Given the paucity of litigation on the effects of these provisions on insurance, this is a contrarian but valid approach.

Direct discrimination is controlled by a variety of methods, as noted above in Part II. The interesting ones for regulators are those in which differential treatment can be justified, but only on the basis of certain criteria. These are the key characteristic

\footnotetext{
${ }^{94}$ On the relational nature of insurance contracts in this regard, see J Feinman, 'The Insurance Relationship as Relational Contract and the Fairly Debatable Rule for First-Party Bad Faith' (2009) 46 San Diego Law Review 553. On the 'pay now, get paid later' nature of the relationship, see $\mathrm{H}$ Beh and J Stempel, 'Misclassifying the Insurance Policy: The Unforced Errors of Unilateral Contract Characterization' (2010-2011) 32 Cardozo Law Review 85.
} 
because factors (such as race) which can never be justified can never be relied upon. Take Sch 3, para 21 and its rules on disability as an exemplar:

(1) It is not a contravention of section 29 , so far as relating to disability discrimination, to do anything in connection with insurance business if-

(a) that thing is done by reference to information that is both relevant to the assessment of the risk to be insured and from a source on which it is reasonable to rely, and

(b) it is reasonable to do that thing.

In the industry discussions I have heard on this, much has been made of para 21(1)(a) as requiring evidence that the source is relevant to risk assessment and from a reliable source (such as actuarial data). I have asked for an explanation then of the role of para 21(1)(b) and have been met with incomprehension. This is an important blind spot. It is not enough to meet the requirements of the first provision, the actions must also be reasonable. This provision, which has never been tested, is the basis for a wide range of interventions on differential pricing on the basis of disability, and age (under the inserted para 20(A)). It has been largely ignored by commentators and deserves close attention by potential enforcement agencies. In particular, the use of protected characteristics in markets where the upper limits of a price decision is not determined by 'risk plus' might be thought to be an unreasonable use of sensitive information.

In respect of indirect discrimination, the price optimisation evidence publicised by the FCA in its recent report reflects the industry position that this occurs, but is justified. The relevant provision states that indirect discrimination is prohibited where 'A [the underwriter] cannot show it to be a proportionate means of achieving a legitimate aim. ${ }^{\text {' }}{ }^{9}$

There is at large an assumption - based on the 'risk plus' model - that the use of pricing mechanism that have an indirectly discriminatory effect but which reflect risk-based pricing is a 'proportionate means of achieving a legitimate aim. But this is to conflate the price point with the audit point. In a world of price optimisation what you charge the consumer only needs to meet the audit point in an aggregate, macro sense. So the underwriter needs to use information related to protected characteristics to assess its overall aggregate risk - this is a legitimate aim - but not to make an individual pricing decision.

What we see here is the use of the Equality Act 2010 as an effective control on pricing decisions even without the use of bespoke financial services models. If I am allowed a gentle criticism of the FCA, it is that it has become the domain of economists, behavioural and otherwise, and there needs to be greater input from lawyers in the use and development of regulatory tools. This proposal provides a floor level of intervention, below which the FCA ought not to drop, and should be implemented for all protected characteristics.

\section{ii. Developing a New Code: Principles Based Governance for the Digital Era}

Behavioural research undertaken on both sides of the Atlantic suggest that suboptimal pricing choices by consumers are not simply a matter of permanent status, recognised as

\footnotetext{
${ }^{95}$ Equality Act 2010, s 19(3)(d).
} 
protected characteristics, but distributed across populations that fall outside the Equality Act 2010. Vulnerability is therefore not merely a matter of status, but of moment. Consumers will be more susceptible to irrational behaviour in particular situations with the market economy. This takes us beyond Akerlof's 'Market for Lemons' and information asymmetry and into the realm of irrational (rather than boundedly rational) conduct. Of course, these tendencies are not evenly distributed across the population and significant variations exist. Economic analysis suggests that price optimisation may be regressive: reducing costs substantially for those who are active consumers, but loading those costs on to those with higher switching costs. ${ }^{96}$

The best relevant example of behavioural effects is 'add-on' insurance products provided at the point of sale. These are sometimes known as 'extended warranties' and provide replacement goods in the event of accidental damage. These policies often overlap considerably with existing household cover and are expensive, given that most of the consumer goods covered decline in value in the face of technological advances. A cutting-edge television in 2010 is no longer cutting edge in 2015, but only a replacement 2010 set (or its current financial worth) is offered. The extraordinary profitability of these products in some markets has been tested experimentally, with significant evidence of customers prepared to pay more than 4.5 times the expected pay-out, and often purchasing the first product encountered in the market. This is not merely evidence of consumer focus on the price charged and not the quality of terms (as in the 'Market for Lemons' problem), but suggests behavioural effects beyond mere bounded rationality. The FCA has written extensively on this, ${ }^{97}$ and it is well described in Baker and Siegelman's excellent paper in the Connecticut Insurance Law Journal. ${ }^{98}$

The FCA is likely to respond to further evidence of pricing issues in financial services markets with a sliding scale of interventions. I expect some practices to be prohibited (where the measured frequency and / or severity of variation from risk-based pricing is notably high) and others met with mandatory information and cooling-off periods, and some left to the market. What is not under detailed consideration is a clear policy and legal basis for these interventions. In essence, the shifting of costs from active consumers to passive ones will not be viewed as socially harmful in itself. The general response, even where the effects are regressive, is likely to mirror Lady Hale's statement of consumer policy from the Abbey National litigation:

As a very general proposition, consumer law in this country aims to give the consumer an informed choice rather than to protect the consumer form making an unwise choice. We buy all sorts of products which a sensible person might not buy and some of which are not good value for money. We do so with our eyes open because we want the product in question more than we want the money. ${ }^{99}$

What the FCA have been unable to identify is a rationale for identifying where intervention is nonetheless required. The six factors do not indicate the point at which

\footnotetext{
${ }^{96}$ See Thomas, 'Non-Risk Price Discrimination in Insurance' (2012) 32.

${ }^{97}$ www.fca.org.uk/publications/market-studies/general-insurance-add-ons-market-study.

${ }^{98}$ T Baker and P Siegelman, "You Want Insurance with That?" Using Behavioral Economics to Protect Consumers from Add-on Insurance Products' (2013) 20 Connecticut Insurance Law Journal 1.

${ }^{99}$ Above n 39.
} 
intervention occurs, nor indeed any comparative weightings. An equivalent indicator of likely future intervention might have to look something like a 'price' version of the grey list of presumptively unfair terms in the unfair terms legislation. ${ }^{100}$ We are a long way from that. The kinds of solutions that work in neo-classical law and economics - better information, to enable better choices - do not seem apt for markets where consumers are selected for their likely propensity to ignore market information.

At this stage, without the experimental evidence to come from focused behavioural economic experimentation, it would be better to use the Equality Act vigorously to set a floor level of protection as guaranteed by primary legislation, and use the secondary legislation and codes sparingly. This carries a greater level of legitimacy, and might diminish the pushback from industry. The FCA should then develop specific pricing standards to apply prospectively (and based on its empirical findings) and commit to regular reassessment of the efficacy of these codes. That task, akin to the drive to create principles-based regulation at the turn of the century, is a substantial research task, and one which will require input not only from economists, but also lawyers. The Fourth Industrial Revolution will require us to restate the basis for regulated capitalist exchange, and the extent to which consumers are to be held responsible for the choices that they make. This paper does not offer easy solutions to this problem, because they do not exist. Credible intervention will require three things:

(1) a clear political choice as to the nature of consumer protection in the digital era;

(2) detailed empirical studies as to the nature of market behaviour and the effects of intervention; and

(3) an iterative approach. This will not be resolved by the application of simple models of consumer conduct.

\section{Conclusion}

The FCA entry into the regulation of insurance pricing was not predicted. It represents a potentially well-resourced and well-informed litigant in a field in which private enforcement of rights has been markedly weak. Insurers should not be criticised for seeking to maximise profitability. But as their business models shift, so must the legal restrictions and associated protections that were put in place to enable that model. As the 'risk plus' vision of insurance pricing retreats, insurers in key markets ought to lose the bespoke access to sensitive personal data that the Equality Act exemptions gave them. In the meantime, those exceptions should be read narrowly to only permit the use of such data in genuinely risk-driven pricing decisions. If consumer insurance is just another capitalist consumer exchange, then insurance exceptionalism should end.

The difficulty with this regulatory impulse is how to restrict it to financial services, as the FCA seems keen to do. The CJEU was adamant that price regulation was not part of the unfair terms system precisely because no system could be designed to decide

\footnotetext{
${ }^{100}$ As found in Consumer Right Acts 2015, Sch 2.
} 
when prices were fair. That was left to market forces. And yet the FCA are developing a model that looks very close to the standard conception of harm through unfair terms by which to decide whether pricing is fair in regulated financial markets. The contradiction is clear: either no system can determine when pricing is fair, or the system as designed is applicable to consumer contracts generally. Price represents one of the last great bastions of common law freedom of contract and yet its underpinnings are being eroded by a process that is likely to be neither judicial nor directly legislative, but by the incremental advance of administrative regulatory action. 